\title{
Penurunan Kadar Amonium dan Fosfat pada Limbah Cair Industri Pupuk
}

\author{
Aulia Rodlia Fitriana dan IDAA Warmadewanthi \\ Jurusan Teknik Lingkungan, Fakultas Teknik Sipil dan Perencanaan, Institut Teknologi Sepuluh \\ Nopember (ITS) \\ Jl. Arief Rahman Hakim, Surabaya 60111 Indonesia \\ e-mail: warma@its.ac.id
}

\begin{abstract}
Abstrak - Limbah cair industri pupuk mengandung kadar amonium dan fosfat yang cukup tinggi. Kadar ini dihasilkan dari kegiatan produksi pabrik amoniak dan pabrik asam fosfat. Penurunan ammonium dan fosfat ini dapat dilakukan melalui proses presipitasi kimiawi dan menghasilkan mineral Magnesium Ammonium Phosphate (MAP) atau Struvite. Sumber Mg yang akan digunakan adalah $\mathrm{MgCl}_{2}$. Penelitian dilakukan dalam skala laboratorium menggunakan sistem batch. Variabel yang digunakan adalah kecepatan pengadukan, $\mathrm{pH}$, dan rasio molar $\left[\mathrm{Mg}^{2+}\right]:\left[\mathrm{NH}_{4}{ }^{+}\right]:\left[\mathrm{PO}_{4}{ }^{3-}\right]$. pH yang akan digunakan adalah 7,$5 ; 8$; dan 8,5. Sedangkan rasio molar yang digunakan adalah 1:1:1; 1,5:1:1; dan 2:1:1. Kedua hasil variabel ini merupakan hasil dari permodelan Visual MINTEQ v3.0. Variasi G.td yang digunakan adalah $0,5.10^{6} ; 1^{6}$; dan $1,5.10^{6}$. Presipitasi dilakukan selama 60 menit dan dilanjutkan dengan proses sedimentasi selama 30 menit. Hasil yang diperoleh pada penelitian ini adalah presentase removal amonium dan fosfat optimum terjadi pada $\mathrm{pH}$ 8,5 dan rasio molar 1:1:1 dengan G.td $10^{6}$ atau setara degan $158 \mathrm{rpm}$. Kadar amonium awal sebesar $2864 \mathrm{mg} / \mathrm{L}$ dan fosfat sebesar $14656 \mathrm{mg} / \mathrm{L}$. Residual amonium sebesar $396,82 \mathrm{mg} / \mathrm{L}$ dan residual fosfat sebesar $148,86 \mathrm{mg} / \mathrm{L}$. Residual amonium dan fosfat pada penelitian ini masih tinggi.
\end{abstract}

Kata Kunci - amonium, fosfat, pengadukan, presipitasi, struvite

\section{PENDAHULUAN}

$\mathrm{L}$ imbah cair industri pupuk dan asam fosfat mengandung amonium dan fosfat yang tinggi. Oleh karena itu sebelum dibuang ke badan air penerima diperlukan pengolahan terlebih dahulu agar effluennya dapat memenuhi baku mutu. Kadar amonium dan fosfat yang tinggi pada perairan akan menyebabkan terjadinya eutrofikasi. Eutrofikasi ini dapat menurunkan kadar DO (Dissolved Oxygen) sehingga akan terjadi kondisi anoksik.

Teknik penurunan kadar fosfat dapat dilakukan dengan cara presipitasi kimiawi. Presipitasi amonium fosfat akan menghasilkan magnesium ammonium phosphate (MAP) atau sering disebut struvite $\left(\mathrm{MgNH}_{4} \mathrm{PO}_{4} \cdot 6 \mathrm{H}_{2} \mathrm{O}\right)$ [1]. Presipitasi amonium fosfat dapat menggunakan berbagai sumber $\mathrm{Mg}$ sebagai agen presipitan. Urutan keunggulan presipitan dalam mereduksi fosfat adalah $\mathrm{MgCl}_{2}>\mathrm{MgSO}_{4}>\mathrm{MgO}>\mathrm{Mg}(\mathrm{OH})_{2}$ $>\mathrm{MgCO}_{3}$ [2]. Pada penelitian ini akan menggunakan $\mathrm{MgCl}_{2}$ sebagai sumber $\mathrm{Mg}$ karena memiliki kelarutan yang tinggi dalam presipitasi struvite.

Presipitasi struvite memiliki beberapa keunggulan antara lain struvite yang dihasilkan dapat melepaskan nutrisi pada tingkat yang lebih lambat dibandingkan dengan pupuk lainnya [3]. Struvite juga digunakan sebagai pupuk dengan kandungan logam rendah dibandingkan dengan batuan fosfat yang ditambang dan dipasok ke industri pupuk [4]. Selain itu struvite menjadi sumber $\mathrm{N}, \mathrm{Mg}^{2+}$, dan $\mathrm{P}$ yang sangat efektif untuk tanaman dan dapat digunakan sebagai pupuk slow release tanpa merusak akar tanaman $[5 ; 6]$.

Presipitasi struvite dipengaruhi oleh beberapa faktor, diantaranya $\mathrm{pH}$, komposisi kimia air limbah (derajat kejenuhan terhadap magnesium, amonium dan fosfat; kehadiran ion lainnya; kekuatan ion) dan suhu larutan [7]. Faktor yang paling berpengaruh pada presipitasi struvite adalah rasio molar $\mathrm{Mg}^{2+}: \mathrm{NH}_{4}{ }^{+}: \mathrm{PO}_{4}{ }^{3-}$ dan $\mathrm{pH}[8]$ serta gradien kecepatan.

Penelitian ini akan menghasilkan rasio molar $\left[\mathrm{Mg}^{2+}\right]:\left[\mathrm{NH}_{4}{ }^{+}\right]:\left[\mathrm{PO}_{4}{ }^{3-}\right], \quad \mathrm{pH}$, dan kecepatan pengadukan optimum dalam presipitasi struvite pada limbah cair Industri Pupuk. Permodelan rasio molar dan $\mathrm{pH}$ dilakukan terlebih dahulu menggunakan software Visual MINTEQ (version 3.0). Setelah didapatkan variasi rasio molar dan $\mathrm{pH}$, barulah dilakukan pengujian terhadap variasi tersebut dalam skala laboratorium. Pengujian dilakukan menggunakan sistem batch dengan $\mathrm{MgCl}_{2}$ sebagai agen presipitan.

\section{METODE PENELITIAN}

Secara keseluruhan pelaksanaan penelitian dibagi dalam dua tahapan, meliputi:

\section{A. Penelitian Pendahuluan}

Tujuan dari tahap ini adalah untuk mengetahui karakteristik air limbah industri pupuk. Parameter yang akan diuji adalah $\mathrm{pH}$, kekeruhan, kadar amonium, kadar fosfat, COD, magnesium, dan kalsium. Pada tahap ini juka akan dilakukan presiksi menggunakan software Visual MINTEQ v3.0. Software ini digunakan untuk memprediksi rasio molar $\left[\mathrm{Mg}^{2+}\right]:\left[\mathrm{NH}_{4}{ }^{+}\right]:\left[\mathrm{PO}_{4}{ }^{3-}\right]$ dan $\mathrm{pH}$ yang potensial terjadi untuk presipitasi struvite. Cara menggunakan Visual MINTEQ yaitu dengan memasukkan data karakteristik limbah serta mengatur $\mathrm{pH}$ yang diinginkan. Nilai variasi $\mathrm{pH}$ yang digunakan adalah 7 - 13 dengan kenaikan $\mathrm{pH}$ 0,5. Rasio molar $\left[\mathrm{Mg}^{2+}\right]:\left[\mathrm{NH}_{4}{ }^{+}\right]:\left[\mathrm{PO}_{4}{ }^{3-}\right]$ yang akan digunakan adalah $1: 1: 1$ hingga 3:1:1 dengan kenaikan molar $\left[\mathrm{Mg}^{2+}\right]$ sebesar 0,5. Kemudian dipilih 3 variasi hasil optimum berdasarkan $\mathrm{pH}$ dan 
rasio molar sebagai variabel penelitian. Variabel kecepatan pengadukan mengacu ada penelitian [9] dan [10]. Penelitian menunjukkan bahwa presipitasi struvite akan terjadi secara maksimal saat $\mathrm{G} \mathrm{x} \mathrm{t}_{\mathrm{d}}$ mendekati $0,5 \times 10^{6}$ [9] dan $10^{6}$ [10]. Kedua variasi $G \times t_{d}$ akan digunakan sebagai dasar dan ditambah satu variasi di atas $10^{6}$ yaitu $1,5 \times 10^{6}$. Pengadukan akan dilakukan selama 60 menit. Jika berdasarkan gradien kecepatan, didapatkan gradien sebesar $139 \mathrm{~s}^{-1} ; 278 \mathrm{~s}^{-1}$; dan $417 \mathrm{~s}^{-1}$. Setelah dikonversikan ke rpm menghasilkan kecepatan sebesar $100 \mathrm{rpm}, 158 \mathrm{rpm}$, dan $207 \mathrm{rpm}$.

\section{B. Penelitian Utama}

Penelitian utama dilakukan secara batch selama 60 menit. Kristal $\mathrm{MgCl}_{2}$ ditimbang sesuai perbandingan rasio molar yang diinginkan. Kemudian ditambahkan pada beaker glass berisi 0,5 $\mathrm{L}$ air limbah dengan perbandingan rasio molar yang telah didapatkan dari 3 hasil optimum permodelan. $\mathrm{pH}$ diatur dengan menambahkan $\mathrm{NaOH} 10 \mathrm{~N}$ dan $20 \mathrm{~N}$ atau $\mathrm{H}_{2} \mathrm{SO}_{4} 10 \mathrm{~N}$ serta dihomogenasi. Kemudian diaduk menggunakan jartest dengan kecepatan berdasarkan varisasi kecepatan pengadukan selama 60 menit. Selama pengadukan, $\mathrm{pH}$ larutan selalu dijaga dan dicek menggunakan $\mathrm{pH}$-meter. Pengadukan ini dilanjutkan dengan proses sedimentasi selama 30 menit. Parameter yang diuji pada tahap ini adalah $\mathrm{pH}$, kekeruhan, kadar amonium, dan kadar fosfat.

Presipitat hasil presipitasi optimum akan dianalisis morfologi dan strukturnya menggunakan SEM-EDX. Presipitat dipisahkan terlebih dahulu dari supernatannya dengan cara penyaringan menggunakan kertas saring Whatman kemudian dikeringkan pada suhu ruangan selama 48 jam [9]. Pengeringan menggunakan oven dihindari karena dapat menyebabkan perubahan struktur presipitat akibat penguapan ikatan amonium maupun hidrat [11]. Analisis SEM-EDX dilakukan oleh Laboratorium Energi LPPM Institut Teknologi Sepuluh Nopember Surabaya.

\section{HASIL DAN PEMBAHASAN}

\section{A. Karakteristik Air Limbah}

Penelitian ini menggunakan dua sumber limbah yaitu limbah cair industri pupuk dan limbah cair industri asam fosfat. Limbah industri pupuk merupakan sumber amonium, sedangkan limbah industri asam fosfat merupakan sumber fosfat. Karakteristik limbah cair kedua industri dapat dilihat pada Tabel 1 dan Tabel 2.

Limbah amonium dan fosfat akan dicampur untuk membuat rasio molarnya menjadi 1:1. Limbah amonium yang dicampurkan sebanyak 7,917 Liter untuk menghasilkan stock limbah campuran sebanyak 15 Liter. Sedangkan limbah fosfat yang dibutuhkan sebanyak 7,083 Liter. Karakteristik limbah setelah dicampur dapat dilihat pada Tabel 3. Berdasarkan kadar amonium dan fosfat pada tabel di bawah maka rasio molar $\left[\mathrm{NH}_{4}{ }^{+}\right]:\left[\mathrm{PO}_{4}{ }^{3-}\right]$ sama dengan $1: 1,03$.
Table 1.

Karakteristik Air Limbah Industri Pupuk

\begin{tabular}{|c|c|c|}
\hline Parameter & Satuan & Nilai \\
\hline Kekeruhan & NTU & 8,3 \\
\hline $\mathrm{pH}$ & - & 9,7 \\
\hline Amonium & $\mathrm{mg} / \mathrm{L}$ & 5234 \\
\hline Kalsium & $\mathrm{mg} / \mathrm{L}$ & 0,29 \\
\hline Magnesium & $\mathrm{mg} / \mathrm{L}$ & 10,64 \\
\hline COD & $\mathrm{mg} / \mathrm{L}$ & 417,01 \\
\hline \multicolumn{3}{|c|}{$\begin{array}{c}\text { Table } 2 . \\
\text { Karakteristik Air Limbah Industri Asam Fosfat } \\
\end{array}$} \\
\hline Parameter & Satuan & Nilai \\
\hline Kekeruhan & NTU & 1736 \\
\hline $\mathrm{pH}$ & - & 1,5 \\
\hline Fosfat & $\mathrm{mg} / \mathrm{L}$ & 30875 \\
\hline Kalsium & $\mathrm{mg} / \mathrm{L}$ & 601,19 \\
\hline Magnesium & $\mathrm{mg} / \mathrm{L}$ & 105,33 \\
\hline COD & $\mathrm{mg} / \mathrm{L}$ & 3600 \\
\hline Silika & $\mathrm{mg} / \mathrm{L}$ & 937,79 \\
\hline \multicolumn{3}{|c|}{$\begin{array}{c}\text { Table } 3 . \\
\text { Karakteristik Air Limbah untuk Proses Pengolahan } \\
\end{array}$} \\
\hline Parameter & Satuan & Nilai \\
\hline Kekeruhan & NTU & 858 \\
\hline $\mathrm{pH}$ & - & 2,5 \\
\hline Fosfat & $\mathrm{mg} / \mathrm{L}$ & 14656 \\
\hline Amonium & $\mathrm{mg} / \mathrm{L}$ & 2864 \\
\hline Kalsium & $\mathrm{mg} / \mathrm{L}$ & 317 \\
\hline Magnesium & $\mathrm{mg} / \mathrm{L}$ & 54,76 \\
\hline COD & $\mathrm{mg} / \mathrm{L}$ & 3675 \\
\hline Fluor & $\mathrm{mg} / \mathrm{L}$ & 679 \\
\hline
\end{tabular}

\section{B. Pemilihan Variabel Penelitian}

Berdasarkan hasil permodelan kemudian dipilih $\mathrm{pH}$ dan rasio molar dimana removal amonium dan fosfat tertinggi. Removal amonium tertinggi ada pada rasio molar 1:1:1; 1,5:1:1; dan 2:1:1. Sedangkan removal tertinggi pada $\mathrm{pH} 8,5$; 9; dan 9,5. Namun untuk mencapai $\mathrm{pH}$ tersebut dibutuhkan penambahan basa yang banyak, sehingga dipilih $\mathrm{pH} 7,5 ; 8$; dan 8,5 dimana pada $\mathrm{pH}$ tersebut memiliki removal yang tidak jauh berbeda. saat $\mathrm{pH}$ yang akan digunakan pada penelitian ini adalah $\mathrm{pH} 7,5 ; 8$; dan 8,5 . Rasio molar yang akan digunakan pada penelitian ini adalah 1:1:1; 1,5:1:1; dan 2:1:1.

\section{Pengaruh Kecepatan Pengadukan}

Presipitasi struvite terdiri dari dua tahap, yaitu nukleasi dan pertumbuhan kristal. Tahap ini mempengaruhi ukuran partikel [12]. Nukleasi tergantung pada kecepatan pengadukan awal, sedangkan pertumbuhannya tergantung pada energi pengadukan [13]. Pada pH optimum, waktu induksi dipengaruhi oleh proses turbulensi fluida [14]. Waktu induksi berkurang jika kecepatan pengadukan bertambah dan nukleasi struvite menjadi cepat.

Berdasarkan Tabel 4, removal fosfat dan amonium akan semakin naik seiring dengan naiknya kecepatan pengadukan. Peningkatan removal ini sesuai dengan pernyataan [10] pada G.td rendah, removal efisiensi fosfat akan rendah, sebaliknya jika G.td meningkat maka removal fosfat akan naik. [15] mengatakan bahwa semakin besar kecepatan pengadukan maka waktu induksi akan semakin menurun dan nukleasi akan terjadi lebih cepat. Namun saat kecepatan pengadukan 207 rpm, removal amonium dan fosfat dapat turun karena pada 
Table 4.

Hubungan Antara Kecepatan Pengadukan dengan Removal Amonium dan Fosfat

\begin{tabular}{|c|c|c|c|c|c|c|}
\hline \multicolumn{7}{|c|}{ Removal (\%) pada Rasio Molar 1:1:1 } \\
\hline \multirow{2}{*}{$\begin{array}{l}\text { Mixing } \\
(\mathrm{rpm})\end{array}$} & \multicolumn{2}{|c|}{$\mathrm{pH} 7,5$} & \multicolumn{2}{|c|}{ pH 8} & \multicolumn{2}{|c|}{$\mathrm{pH} 8.5$} \\
\hline & $\mathrm{NH}_{4}$ & $\mathrm{PO}_{4}$ & $\mathrm{NH}_{4}$ & $\mathrm{PO}_{4}$ & $\mathrm{NH}_{4}$ & $\mathrm{PO}_{4}$ \\
\hline 100 & 71.06 & 95.28 & 76.93 & 97.48 & 82.13 & 98.89 \\
\hline 158 & 67.39 & 95.25 & 66.67 & 97.56 & 86.14 & 98.98 \\
\hline 207 & 62.01 & 95.13 & 64.62 & 97.02 & 78.22 & 97.71 \\
\hline \multicolumn{7}{|c|}{ Removal (\%) pada Rasio Molar 1,5:1:1 } \\
\hline Mixing & \multicolumn{2}{|c|}{$\mathrm{pH} 7,5$} & \multicolumn{2}{|c|}{ pH 8} & \multicolumn{2}{|c|}{$\mathrm{pH} 8.5$} \\
\hline$(\mathrm{rpm})$ & $\mathrm{NH}_{4}$ & $\mathrm{PO}_{4}$ & $\mathrm{NH}_{4}$ & $\mathrm{PO}_{4}$ & $\mathrm{NH}_{4}$ & $\mathrm{PO}_{4}$ \\
\hline 100 & 58.34 & 99.48 & 69.80 & 99.94 & 69.61 & 93.22 \\
\hline 158 & 56.63 & 99.85 & 83.60 & 99.91 & 70.98 & 99.96 \\
\hline 207 & 56.14 & 99.77 & 72.35 & 99.91 & 75.09 & 99.98 \\
\hline \multicolumn{7}{|c|}{ Removal (\%) pada Rasio Molar 2:1:1 } \\
\hline Mixing & \multicolumn{2}{|c|}{$\mathrm{pH} 7,5$} & \multicolumn{2}{|c|}{$\mathrm{pH} 8$} & \multicolumn{2}{|c|}{ pH 8.5} \\
\hline$(\mathrm{rpm})$ & $\mathrm{NH}_{4}$ & $\mathrm{PO}_{4}$ & $\mathrm{NH}_{4}$ & $\mathrm{PO}_{4}$ & $\mathrm{NH}_{4}$ & $\mathrm{PO}_{4}$ \\
\hline 100 & 95.28 & 76.93 & 97.48 & 82.13 & 98.89 & 58.34 \\
\hline 158 & 95.25 & 66.67 & 97.56 & 86.14 & 98.98 & 56.63 \\
\hline 207 & 95.13 & 64.62 & 97.02 & 78.22 & 97.71 & 56.14 \\
\hline
\end{tabular}

pengadukan tinggi, stabilitas kristal struvite dapat menurun dan menyebabkan kristal pecah [15].

Sehingga kecepatan pengadukan optimum pada penelitian ini terjadi pada G.td $10^{6}$ atau setara dengan 158 rpm dengan waktu pengadukan 60 menit. Kecepatan 207 rpm tidak dipilih karena pada kecepatan ini terjadi pemecahan kristal dan menurunkan stabilitas kristal. Selain itu jika kecepatannya semakin besar maka energi listrik yang dibutuhkan semakin besar pula. Kecepatan pengadukan $100 \mathrm{rpm}$ tidak dipilih karena energi yang dibutuhkan untuk pencampuran $\mathrm{Mg}$ dalam larutan masih kurang untuk beberapa rasio molar.

\section{Pengaruh $\mathrm{pH}$}

$\mathrm{pH}$ akan mempengaruhi kelarutan struvite dan sifat termodinamikanya [16]. $\mathrm{pH}$ akan semakin menurun selama presipitasi oleh karena itu $\mathrm{pH}$ harus selalu dikontol. Pengontrolan $\mathrm{pH}$ akan menggunakan larutan $\mathrm{NaOH} 10 \mathrm{~N}$ dan $20 \mathrm{~N}$ serta akan digunakan $\mathrm{H}_{2} \mathrm{SO}_{4}$ jika pH-nya terlalu basa.

Penurunana $\mathrm{pH}$ disebabkan karena terjadinya induksi. Menurut [17], waktu induksi terjadi pada menit ke $7-14$. Menurut [18], penurunan $\mathrm{pH}$ awal terjadi karena percampuran dan pelarutan Mg. Penurunan $\mathrm{pH}$ yang kedua terjadi karena pelepasan proton selama pembentukan struvite. Pada penggunaan $\mathrm{MgCl}_{2}$ juga akan menurunkan $\mathrm{pH}$ karena pembentukan struvite yang cepat. $\mathrm{pH}$ ini akan seimbang kembali saat penambahan $\mathrm{NaOH}$.

Semakin meningkatnya tingkat kejenuhan dan proses pembentukan nukleus maka $\mathrm{pH}$ akan semakin menurun. Semakin tinggi $\mathrm{pH}$ maka kekeruhan larutan akan semakin besar pula. Pada subbab ini akan membahas tentang pengaruh $\mathrm{pH}$ terhadap presipitasi struvite dengan kecepatan pengadukan optimum yang telah dipilih pada subbab sebelumnya. Tabel 5 menampilkan hubungan antara removal amonium dan fosfat terhadap $\mathrm{pH}$ untuk setiap rasio molar dengan kecepatan pengadukan $158 \mathrm{rpm}$.
Variasi $\mathrm{pH}$ dapat mempengaruhi kelarutan atau formasi kristal struvite [19]. Kelarutan struvite akan berkurang jika $\mathrm{pH}$ meningkat. Kelarutan minimum dapat menyebabkan pembentukan kristal struvite lebih potensial [20] sehingga removal amonium dan fosfat dapat meningkat.

Table 5.

Hubungan Antara pH dengan Removal Amonium dan Fosfat

\begin{tabular}{rrrrr}
\hline \hline \multicolumn{5}{c}{ Removal (\%) pada Rasio Molar 1:1:1 } \\
\hline \multicolumn{4}{c}{$\mathrm{NH}_{4}$} & \multicolumn{2}{c}{$\mathrm{PO}_{4}$} \\
& permodelan & penelitian & permodelan & penelitian \\
7.5 & 90.28 & 67.39 & 95.96 & 95.25 \\
8 & 91.70 & 66.67 & 97.42 & 97.56 \\
8.5 & 92.79 & 86.14 & 98.54 & 98.98
\end{tabular}

$\mathrm{pH} \quad \begin{array}{ll}\mathrm{Nemoval}(\%) \\ \mathrm{NH}_{4}\end{array} \mathrm{PO}_{4}$

$\begin{array}{rrrrr} & \text { permodelan } & \text { penelitian } & \text { permodelan } & \text { penelitian } \\ 7.5 & 76.16 & 56.63 & 99.93 & 99.85 \\ 8 & 75.58 & 83.60 & 99.98 & 99.91 \\ 8.5 & 73.74 & 70.98 & 99.99 & 99.96\end{array}$

Removal (\%) pada Rasio Molar 2:1:1

\begin{tabular}{rrrrr}
$\mathrm{pH}$ & \multicolumn{2}{c}{$\mathrm{NH}_{4}$} & \multicolumn{2}{c}{$\mathrm{PO}_{4}$} \\
& permodelan & penelitian & permodelan & penelitian \\
7.5 & 65.60 & 52.10 & 99.95 & 99.90 \\
8 & 64.77 & 61.29 & 99.99 & 99.98 \\
8.5 & 62.17 & 56.40 & 100.00 & 99.95 \\
\hline
\end{tabular}

Namun pada pH 8,5 removal fosfat dan amonium akan menurun. Penurunan removal ini disebabkan karena terbentuknya mineral $\mathrm{MgF}_{2}(\mathrm{~s})$. Berdasarkan hasil permodelan pembentukan $\mathrm{MgF}_{2}$ (s) akan semakin meningkat seiring dengan meningkatnya $\mathrm{pH}$. Ion fosfat dan amonium akan berkompetisi dengan ion fluor untuk berikatan dengan magnesium. Namun pembentukan $\mathrm{MgF}_{2}(\mathrm{~s})$ ini tidak berpengaruh banyak terhadap penurunan removal karena $\mathrm{MgF}_{2}(\mathrm{~s})$ yang terbentuk tidak sebanding dengan struvite. Reaksi pembentukan $\mathrm{MgF}_{2}$ (s) dapat dilihat pada persamaan Reaksi 1 .

$\mathrm{Mg}^{2+}+2 \mathrm{~F}^{-} \leftrightarrow \mathrm{MgF}_{2}(\mathrm{~s}$

Penurunan removal amonium juga disebabkan karena terbentuknya mineral bobierrite. [21] menyatakan bahwa kelarutan bobierrite berkurang ketika pH berubah dari 8 ke 9 . Bobierrite akan menjadi sangat dominan pada $\mathrm{pH} 8-10$. Dari penjelasan yang telah dipaparkan di atas, maka dapat ditarik kesimpulan bahwa $\mathrm{pH}$ optimum dalam presipitasi struvite adalah 8,5. Walaupun pada $\mathrm{pH} 8,5$ ini dapat terbentuk mineral lain selain struvite.

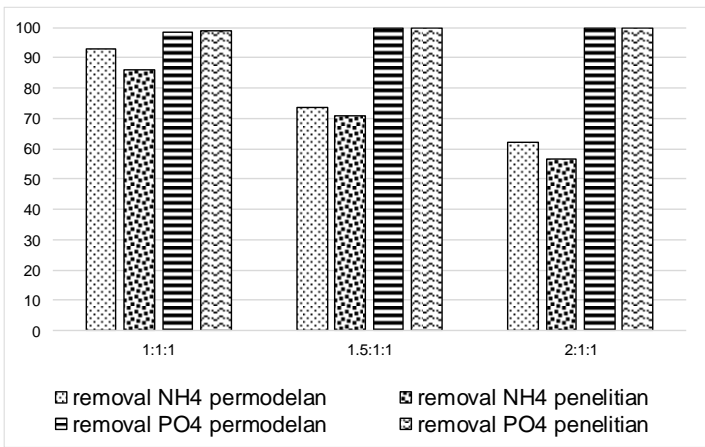

Gambar 1. Pengaruh rasio molar terhadap removal amonium dan fosfat pada $\mathrm{pH} 8,5$ dan kecepatan $158 \mathrm{rpm}$ 


\section{E. Pengaruh Rasio Molar}

Penambahan magnesium yang berlebih dapat meningkatkan removal efisiensi proses, tetapi juga dapat menurunkan kemurnian struvite yang terbentuk [22; 9].

Gambar 1 terlihat bahwa removal amonium akan semakin menurun seiring dengan pertambahan rasio molar. Semakin besarnya penambahan $\mathrm{Mg}$ pada $\mathrm{pH}$ basa dapat menyebabkan terbentuknya bobierrite. Bobierrite menyebabkan removal amonium semakin menurun karena magnesium hanya akan mengikat fosfat saja. Semakin besar rasio molar Mg maka semakin besar removal fosfat. Magnesium mempengaruhi level supersaturasi dan laju proses presipitasi [15]. Tingginya kadar magnesium dapat meningkatkan removal fosfat. Pada $\mathrm{pH}$ yang diberikan, setiap penambahan rasio molar dapat meningkatkan derajat saturasi pembentukan struvite, sehingga mempengaruhi removal fosfat [23]. Removal $\mathrm{NH}_{4}$ penelitian isan di atas maka dapat disimpulkan $\mathrm{t}^{\text {Removal } \mathrm{PO}_{4} \text { penelitian vite }}$ secara optimum terjadi pada rasio molar $\left[\mathrm{Mg}^{2+}\right]$ : $\left[\mathrm{NH}_{4}{ }^{+}\right]$: $\left[\mathrm{PO}_{4}{ }^{3-}\right]$ sama dengan 1:1:1. Keadaan ini terjadi pada $\mathrm{pH} 8,5$ dan kecepatan pengadukan $158 \mathrm{rpm}$ atau setara dengan G.td $10^{6}$.

\section{F. Identifikasi Struvite Menggunakan SEM-EDX}

Analisis Scanning electron microscope (SEM) dan Energy dispersive X-ray spectroscopy (EDX) bertujuan untuk
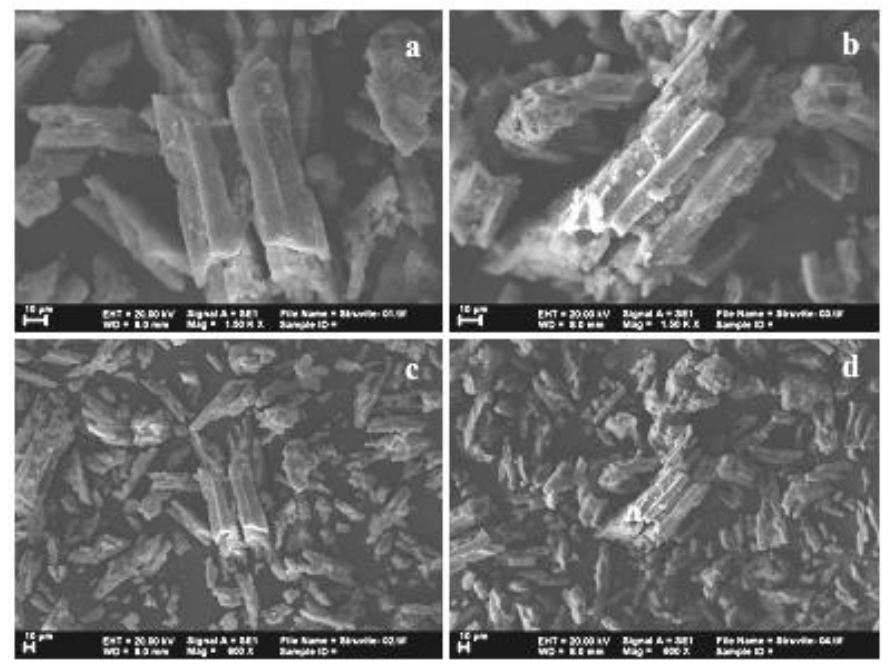

Gambar 2 Bentuk Struvite pada Perbesaran 1500x (a, b) dan 600x (c, d)

Table 6.

Elemen - elemen pada Presipitat

\begin{tabular}{|c|c|c|c|c|c|c|}
\hline $\mathrm{El}$ & AN & Series & $\begin{array}{l}\text { unn. C } \\
\text { [wt.\%] }\end{array}$ & $\begin{array}{c}\text { norm. C } \\
\text { [wt.\%] }\end{array}$ & $\begin{array}{c}\text { Atom. C } \\
\text { [at.\%] }\end{array}$ & $\begin{array}{c}\text { Error } \\
{[\%]}\end{array}$ \\
\hline $\mathrm{C}$ & 6 & K-series & 25.74 & 25.74 & 34.79 & 8.8 \\
\hline $\mathrm{N}$ & 7 & K-series & 0.00 & 0.00 & 0.00 & 0.0 \\
\hline $\mathrm{O}$ & 8 & K-series & 42.24 & 42.24 & 42.84 & 13.9 \\
\hline $\mathrm{F}$ & 9 & K-series & 13.69 & 13.69 & 11.69 & 5.5 \\
\hline $\mathrm{Na}$ & 11 & K-series & 1.22 & 1.22 & 0.86 & 0.1 \\
\hline $\mathrm{Mg}$ & 12 & K-series & 6.47 & 6.47 & 4.32 & 0.4 \\
\hline $\mathrm{Si}$ & 14 & K-series & 0.45 & 0.45 & 0.26 & 0.0 \\
\hline $\mathrm{P}$ & 15 & K-series & 8.84 & 8.84 & 4.63 & 0.4 \\
\hline $\mathrm{S}$ & 16 & K-series & 0.65 & 0.65 & 0.33 & 0.1 \\
\hline \multirow[t]{2}{*}{$\mathrm{Ca}$} & 20 & K-series & 0.67 & 0.67 & 0.27 & 0.0 \\
\hline & & Total & 100.00 & 100.00 & 100.00 & \\
\hline
\end{tabular}

identifikasi kristal yang terbentuk. SEM-EDX juga bertujuan untuk mengetahui komposisi kimia, karakteristik permukaan, serta morfologi dan struktur presipitat. Sampel yang akan dianalisa adalah presipitat hasil optimum, yaitu pada $\mathrm{pH} 8,5$ rasio molar 1:1:1 dan kecepatan pengadukan $158 \mathrm{rpm}$. Analisis SEM ini dilakukan pada perbesaran 600x dan 1500x.

Kristal struvite murni akan memiliki bentuk batang dengan ujung runcing dan pemukaannya bersih dan tanpa cacat [24]. Kristal pada penelitian ini berbentuk batang ujung runcing dan terdapat gumpalan kecil pada permukaannya. Gumpalan tersebut merupakan mineral pengotor yang terbentuk selama proses presipitasi. Mineral tersebut berupa hydroxyapatite, bobierrite, dan $\mathrm{MgF}_{2}$. Menurut [25], fluor dapat menyebabkan presipitat menjadi cacat dan berukuran kecil. Ion pengotor dapat menghambat laju pertumbuhan karena ion tersebut memblokir bagian pertumbuhan yang aktif, sehingga kristal berukuran kecil. Kehadiran kalsium ini juga akan menyebabkan terganggunya kristalisasi struvite, mengurangi ukuran kristal dan menghambat pertumbuhan struvite [26].

Berdasarkan Gambar 2 dan Tabel 11 terdapat beberapa unsur pada presipitat antara lain $\mathrm{Mg}, \mathrm{P}, \mathrm{O}, \mathrm{N}, \mathrm{C}, \mathrm{F}, \mathrm{Na}, \mathrm{Ca}, \mathrm{Si}$, dan S. pada Tabel 5, elemen $\mathrm{N}$ tidak terbaca karena kemungkinan terjadinya penguapan selama pengeringan presipitat. Unsur tersebut berasal dari limbah, sedangkan unsur $\mathrm{Na}$ berasal dari penambahan $\mathrm{NaOH}$ saat kontol pH. Silika (Si) terdapat dalam presipitat karena elemen ini dapat dijadikan inti kristal saat proses nukleisasi [27]. Kadar Flour dalam presipitat memiliki nilai yang cukup tinggi, sehingga fluor ini dapat mengganggu presipitasi struvite.

Unsur $\mathrm{N}$ dianalisis menggunakan metode wet-analysis. Wet-analysis dilakukan dengan cara melarutkan presipitat ke dalam $5 \mathrm{ml} \mathrm{HNO}_{3} 1 \mathrm{~N}$ kemudian ditambah aquadest hingga $500 \mathrm{ml}$ dan diaduk menggunakan magnetic stirrer selama 1 jam. Kandungan amonium dalam presipitat mencapai 89,818 $\mathrm{mg} / \mathrm{gram}$.

\section{KESIMPULAN DAN SARAN}

Kesimpulan yang dapat ditarik dari penelitian ini adalah:

1) Kecepatan pengadukan optimum pada penelitian ini terjadi pada kecepatan $158 \mathrm{rpm}$ atau setara dengan G.td $10^{6}$.

2) $\mathrm{pH}$ optimum pada penelitian ini terjadi pada $\mathrm{pH} 8,5$.

3) Rasio molar optimum pada penelitian ini terjadi pada rasio $\left[\mathrm{Mg}_{2}{ }^{+}\right]:\left[\mathrm{NH}_{4}{ }^{+}\right]:\left[\mathrm{PO}_{4}{ }^{3-}\right]$ sama dengan 1:1:1. Hasil residual amonium dari penelitian ini sebesar $396,82 \mathrm{mg} / \mathrm{L}$ dan residual fosfat sebesar $148,86 \mathrm{mg} / \mathrm{L}$.

Saran untuk penelitian selanjutnya, antara lain:

1) Diperlukan pengolahan pendahuluan untuk menurunkan kadar Fluor pada limbah. Kehadiran ion ini pada kadar yang tinggi dapat menyebabkan penurunan removal amonium dan fosfat.

2) Diperlukan pengolahan lanjutan lagi untuk menyisihkan fosfat karena residual fosfat pada penelitian ini masih melebihi baku mutu yang ditetapkan 


\section{UCAPAN TERIMA KASIH}

Penulis mengucapkan terima kasih kepada Dosen Pembimbing dan Dosen Penguji Tugas Akhir atas bimbingan, saran, dan masukan dalam penulisan jurnal ini.

\section{DAFTAR PUSTAKA}

[1] Tünay, O., Kabdasli, I. Orhon, D. dan Kolçak, S, “Ammonia removal by magnesium ammonium phosphate in industrial wastewaters" Wat. Sci. Technol, (1997) 36 (2-3) : 225-228.

[2] Zeng, L., dan Li, X., "Nutrient Removal from Anaerobically Digester Cattle Manure by Struvite Precipitation" Journal of Enviromental Enggineering and Science, Vol 5 (2006) Issue 4. P285.

[3] Münch, von E. dan Barr, K., "Controlled struvite crystallization for removing phosphorus from anaerobic digester sidestreams" Water Res. (2001) 35: 151-9.

[4] Driver, J., Lijmbach, D., dan Steen, I., "Why Recovery Phosphorus for Recycling and How?" Environ. Technol. (1999) 20(7), 651-662.

[5] Priestley, A.J., Cooney, E., Booker, N.A. dan Fraser, I.H., "Nutrients in Wastewaters-Ecological Problem or Commercial Opportunity" Proceedings of the 17 th Federal Convention of the Australian Water and Wastewater Association, Melbourne, (1997) 1. 340-346.

[6] Gaterell, M.R., Gay, R., Wilson, R., Gochin, R.J. dan Lester, J.N., “An Economic and Environmental Evaluation of the Opportunities for Substituting Phosphorus Recovered From Wastewater Treatment Works in Existing UK Fertiliser Markets" Env. Tech. (2000) 21. 1067-1084.

[7] Khai, N. M. dan Hoang T. Q. T., "Chemical Precipitation of Ammonia and Phosphate from Nam Son Landfill Leachate, Hanoi" Iranica Journal of Energy \& Environment 3 (Special Issue on Environmental Technology) (2012) 32-36.

[8] Kumar, R. dan Pal, P., "Turning Hazardous Waste Into ValueAdded Products: Production and Characteristization of Struvite Ammonical Waste with New Approaches" Journal of Cleaner Production Vol. 43 (2013), pp: 59-70.

[9] Warmadewanthi dan Liu, J.C., "Recovery of fosfat and amonium as struvite from semiconductor wastewater" Separation and Purification technology (2009) 64(1-3). hal 368-373.

[10] Kim, D., Kim, J., Ryu, H.-D., dan Lee, S.-I., "Effect of Mixing on Spontaneous Struvite Pecipitation from Semiconductor Wastewater" Journal of Bioresource Technology 100 (2009) 74-78.

[11] Laconi, C.D., Pagano, M., Ramadori, R. dan Lopez, A., "Nitrogen Recovery from A Stabilized Municipal Landfill Leachate" Journal of Biosource Technology. Vol. 101 (2010), pp: 1732-1736.

[12] Doyle, J. D. dan Parsons, S. A., "Struvite Formation, Control and Recovery” Water Res. (2002) 36(16), 3925-3940.

[13] Jones, A. G., "Crystallization Process System. Butterworth" Heinemann : UK (2002).

[14] Ohlinger, K. N., Young, T. M., dan Schroeder, E. D., "Kinetics effects on preferential struvite accumulation in wastewater" Journal of Environmental Engineering (1999) 125(8), 730-737.

[15] Rahaman, M. S., Ellis, N. dan Mavinic, D.S., "Effects of Various Process Parameters on Struvite Precipitation Kinetics and Subsequent Determination of Rate Constants" Wat. Sci. tech. (2008) 57(5), 647 654

[16] Ronteltap, M., Maurer, M., dan Gujer, W. "Struvite precipitation thermodynamics in source-separated urine" Water Res. 5, (2007) 977984.

[17] Kofina, A.N. dan Koutsoukos, P.G., "Nucleation and growth of struvite from synthetic wastewater" International Conference on struvite: its role in phosphorus recovery and reuse, Cranfield : UK (2004).

[18] Stolzenburg, P., Capdevielle, A., Teychené, S., dan Biscans, B., "Struvite precipitation with $\mathrm{MgO}$ as a precursor: Application to wastewater treatment" Chemical Engineering Science (2015) 133, 9-15

[19] Parsons, S.A., Wall F., Doyle, J., Oldring, K., dan Churchley, J., "Assessing the potential for struvite recovery at sewage treatment works" Environmental Technology, (2001) 22 (11), 1279-1286

[20] Escudero, A., Blanco, F., Lacalle, A., dan Pinto, M., "Struvite precipitation for ammonium removal from anaerobically treated effluents" Journal of Environmental Chemical Engineering 3, (2015) 413-419
[21] Sugiyama, S., Yokoyama, M., Ishizuka, H., Sotowa, K. -I., Tomida, T., dan Shigemoto, N., "Removal of aqueous ammonium with magnesium phosphate obtained from the ammonium-elimination of magnesium ammonium phosphate" J. Colloid Interface Sci., (2005) 2921, 133-138.

[22] Wang, J., Burken, J.G., dan Zhang, X.Q., "Effect of seeding materials and mixing strength on struvite precipitation" Water Environment Research (2006) 78, 125-132.

[23] Adnan, A., Dastur, M., Mavinic, D.S., dan Koch, F.A.. "Preliminary investigation into factors affecting controlled struvite crystallization at the bench scale" J. Environ. Eng. Sci., (2004) 3, 195-202.

[24] Suguna, K., Thenmozhi, M., dan Sekar, C., "Growth, spectral, structural and mechanical properties of struvite crystal grown in presence of sodium fluoride" Bull. Mater. Sci., Vol. 35, (2012) No. 4, pp. 701-706.

[25] Kabdasli, I., Parson, S. A., dan Tunay, O., "Effect of major ions on induction time of struvite precipitation" Croatica Chemica Acta (2006) 79(2). 243-251.

[26] Corre, K. S. L., Jones, V. E., Hobbs, P., dan Parsons, S. A. "Impact of calcium on struvite crystal size, shape and purity" Journal of Crystal Growth 283, (2005) 514-522.

[27] Yang, L., Zhou, H., dan Moccia, R., "Membrane filtration coupled with chemical precipitation to treat recirculation aquaculture system effluent." J. Environ. Qual., (2006) 356, 2419-2424. 